\title{
GAMBARAN PENGEMBANGAN PROGRAMI STUDI PENDIDIKAN AGAMA ISLAMI (PAI) PADA FAKULTAS TARBIYAH DAN KEGURUAN UIN ALAUDDIN MAKASSAR
}

\author{
Rosdiana \\ Fakultas Tarbiyah dan Keguruan UIN Alauddin Makassar \\ Jl. H. M. Yasin Limpo No. 36 Samata, Gowa
}

\begin{abstract}
This study examines the prospect of developing the study program of Islamic Education (PAI) at the Faculty of Tarbiyah and Teacher Training UIN Alauddin Makassar. Focused on two sub issues, namely: (1) Efforts to develop PAI study program at the Faculty of Tarbiyah and Teacher Training UIN Alauddin Makassar; (2) Supporting factors and inhibiting the development of PAI Faculty of Tarbiyah and Teacher Training Program UIN Alauddin Makassar. The type of research is qualitative with managerial, phenomenological and sociological approach. The data sources consist of documentation on PAI Study Program, Alumni of PAI study program, staff, and lecturer of Faculty of Tarbiyah and teacher of UIN Alauddin Makassar as informant. Data collection using interviews, documentation, and observation. Technique of analysis / data processing in three ways, namely data reduction, data display, and data verification. Test the validity of informant data by using triangulation.

The result of the research shows that there are five efforts conducted by managers in the development of PAI study program at the Faculty of Tarbiyah and Teacher Training UIN Alauddin Makassar, namely: (1) Efficiency and effectiveness of leadership; (2) Program evaluation and graduate tracking; (3) Program development planning; (4) Cooperation and partnership; (5) Program evaluation on the experience and quality of student learning. Factors supporting the development of PAI study program at the Faculty of Tarbiyah and Teacher Training UIN Alauddin Makassar, namely: (1) Experience in development; (2) Quality of lecturer; (3) Government support; (4) Many enthusiasts (student quantity). While the inhibiting factors are (1) Infrastructure is not yet complete; (2) Unsatisfactory lecturer discipline; (3) Source of fund has not been socialized (Faculty).

The implication of this research is the need to systematize the learning process in accordance with the needs of the alumni of PAI study program and require support from all parties, namely the cooperation that is considered to be competent in the field including the Ministry of Religious Affairs in the field of Mapenda. In order to formulate and realize the learning that has character, methodological, skilled, has the value of Qurani, scientific, educational and can be developed based on the curriculum of learning. The management of learning can not be separated from the facility of study program, lecturer competence, students and organization of study program of PAI who have successfully obtained accreditation A.
\end{abstract}

Keywords: Development, Study Program, PAI. 


\section{PENDAHULUAN}

$\mathrm{P}$ rogram studi pendidikan agama Islam merupakan sub sistem dari sistem masyarakat atau bangsa. Dalam operasionalnya selalu mengacu dan tanggap kepada perkembangan kebutuhan masyarakat. Tanpa sikap demikian, lembaga pendidikan dapat menimbulkan kesenjangan sosial dan kultural. Kesenjangan inilah yang menjadi salah satu sumber konflik antara pendidikan dan masyarakat. Dari sinilah muncul krisis pendidikan yang intensitasnya berbeda-beda menurut tingkat atau taraf masyarakat. ${ }^{1}$

Untuk mengetahui adanya kesenjangan antara lembaga pendidikan dan masyarakat yang berkenan dengan kebutuhan yang meningkat ialah dengan melakukan assessment. Assessment ini penting dilakukan untuk mengetahui pelaksanaan dan ketercapaian tujuan dari lembaga pendidikan.

Azyumardi Azra mengungkapkan suatu keprihatinan terhadap prestasi lembaga pendidikan Islam yang masih menempati posisi marjinal. Pengembangannya secara umum masih kurang profesional, bahkan seringkali kalah bersaing dalam berbagai segi dengan sub sistem pendidikan Nasional yang diselenggarakan oleh kelompok-kelompok masyarakat lain. Bukan rahasia lagi, bahwa citra dan gengsi lembaga pendidikan Islam sering dipandang sebagai sub ordinat dari pendidikan yang diselenggarakan pihak lain. ${ }^{2}$

Kaitannya dengan statement tentang posisi lembaga pendidikan Islam tersebut, Mochtar Naim menuding bahwa dualisme dan dikotomi pendidikan yang diwariskan pemerintah kolonial, setidaknya, sebagai penyebab utama. Beberapa dampak negatif yang ditimbulkan oleh sistem yang dualistik ini menurutnya adalah: Pertama, arti agama telah dipersempit yaitu sejauh yang berkaitan dengan aspek teologi Islam seperti yang diajarkan di sekolah-sekolah agama selama ini. Kedua, sekolah-sekolah agama telah terkucil dalam buku tersendiri dan menjadi eksklusif. Ketiga, sumber masukan sekolah agama dan perguruan tinggi agama Islam sangat rendah dan residual, dan karena masuknya residual maka mutu tamatannya adalah medioker (tergolong kelas dua). ${ }^{3}$

Dua pendapat di atas memperlihatkan benang merah dari kelemahan besar yang diperlihatkan oleh lembaga pendidikan Islam yakni kelemahan menejerial, eksklusifitas dan rendahnya prestasi. Jika diamati, maka ketiga titik lemah tersebut, kesemuanya merupakan permasalahan yang sangat esensial. Inilah kemudian yang diusahan untuk dihindari oleh Fakultas Tarbiyah dan Keguruan UIN Alauddin Makassar dengan terus melakukan pengembangan dalam sitem pendidikannya.

${ }^{1}$ Muhaimin, Paradigma Pendidikan Islam Upaya Mengefektifkan Pendidikan Agama Islam di Sekolah (Cet. II; Bandung: PT. Remaja Rosdakarya, 2002), h. 35.

2 Azyumardi Azra, Pendidikan Islam, Tradisi dan modernisasi menuju Milenium Baru (Cet. I; Jakarta: Logos, 1999), h. 147.

${ }^{3}$ Marwan Saridjo, Bunga Rampai Pendidikan Agama Islam (Cet. I; Jakarta: Amisco, 1999), h. 27. 
Program studi Pendidikan Agama Islam pada Fakultas Tarbiyah dan Keguruan UIN Alauddin Makassar merupakan tentunya harus menyesuaikan diri dengan perkembangan global untuk tetap eksis di era modern. Program studi PAI perlu menghasilkan out put sumber daya manusia yang mampu memahami dan menguasai ilmu pengetahuan dan teknologi. Dalam menyelenggarakan program pendidikan didasari oleh Visi Fakultas Tarbiyah dan Keguruan UIN Alauddin Makassar yaitu menjadi pusat ungulan pengembangan pendidikan Islam dan tenaga kependidikan yang profesional. Misi meningkatkan kualitas sumber daya manusia dengan mengembangkan sikap ilmiah, keterampilan dan aplikasi nilai-nilai akhlakul karimah, serta meningkatkan kualitas pelayanan dengan mengutamakan kecepatan, ketepatan dan kelayakan. ${ }^{4}$ Hal ini dijabarkan dalam pembinaan peserta didik seoptimal mungkin yang dilaksanakan melalui proses pendidikan yang bermartabat, kreatif, inovatif, experimentatif, menumbuhkan dan mengembangkan bakat, minat, dan kemampuan peserta didik. Jadi peserta didik harus diberi perlakuan secara maksimal untuk mengaktualkan potensi intelektual, emosional, dan spiritualnya. ${ }^{5}$

Berdasarkan landasan filosofis tersebut dan permasalahan yang diungkapkan sebelumnya, penting untuk mengkaji pelaksanaan pengembangan Program Studi Pendidikan Agama Islam Fakultas Tarbiyah dan Keguruan UIN Alauddin Makassar, sebagai bahan evaluasi dan lebih baiknya ke depan.

\section{PEMBAHASAN}

\section{A. Hakikat Pengembangan Program Studi PAI}

Pengembangan program studi PAI terhadap mutu pendidikan mulai meningkat. Undang-undang ini banyak menitik beratkan pada monitoring 'performance indicators" (indikator kinerja) dari proses pendidikan. Akan tetapi indikator-indikator ini, terutama hanya merupakan pedoman untuk mengukur efisiensi mutu pembelajaran atau efektivitas institusi dalam memenuhi kebutuhan pelanggan. Jika ingin memperoleh lebih banyak apa yang ada di balik indikator kinerja tersebut, suatu institusi harus di mulai lebih serius pada Total Quality Management (TQM) dengan artian perbaikan berkelanjutan (continuous improvement) terhadap standar pelanggannya seiring meningkatnya persyaratan mutu pelanggan. ${ }^{6}$

Perbaikan mutu menjadi semakin penting dengan meningkatnya persaingan dalam era liberalisasi ini. Otonomi yang semakin besar, harus diimbangi oleh peningkatan tanggung jawab. Lembaga pendidikan tinggi harus bisa mendemonstrasikan bahwa lembaga tersebut mampu menyelenggarakan pendidikan yang bermutu kepada para mahasiswanya. Hal ini sejalan dengan paradigma baru penataan sistem pendidikan

\footnotetext{
${ }^{4}$ Profil Fakultas Tarbiyah dan Keguruan UIN Alauddin Makassar tahun 2006, h. 64

${ }^{5}$ Profil Fakultas Tarbiyah dan Keguruan UIN Alauddin Makassar tahun 2006, h. 65

${ }^{6}$ Ahmad Rumi, Ensiklopedi Manajemen (Jakarta: Bumi Aksara, 1994), h. 132
} 
tinggi, yang mulai diterapkan pada Sistem Perencanaan Penyusunan Program dan Pengajaran (SP4). Perguruan tinggi harus menyelenggarakan pendidikan yang mengacu kepada mutu yang berkelanjutan. Untuk itu diperlukan pola manajemen yang berasaskan otonomi, namun diiringi akuntabilitas yang memadai. ${ }^{7}$

Hal ini hanya akan bisa dicapai bila suatu perguruan tinggi melakukan evaluasi diri secara teratur sebelum dievaluasi oleh pihak ketiga secara eksternal yakni akreditasi. Evaluasi secara teratur dalam bentuk 'audit internal' yang dilanjutkan dengan "review sistem manajemen" akan menjamin suatu perguruan tinggi dapat secara kontinyu melakukan perbaikan mutu, dalam mengantisipasi persaingan yang semakin ketat bagi lulusannya dalam meniti karir di dunia kerja. ${ }^{8}$

Dalam rangka melaksanakan perbaikan mutu di perguruan tinggi/ universitas/fakultas dan program studi khususnya PAI, secara kontinyu (berkelanjutan), Total Quality Management (TQM) merupakan pendekatan yang tepat. TQM merupakan kegiatan pikiran (sikap, gagasan) dan kegiatan praktis (metoda, prosedur, teknik) yang mendorong perbaikan secara kontinyu. Sebagai suatu pendekatan, TQM mengupayakan agar penekanan institusi bergeser secara permanen dan 'shorter expediency', keperbaikan mutu jangka panjang, inovasi, perbaikan dan perubahan yang terus menerus, perlu ditekankan. Di samping itu, unit-unit kerja yang melaksanakan dilibatkan dalam siklus perbaikan mutu yang kontinyu. Gerakan perbaikan mutu dalam bidang pendidikan di UIN Alauddin, sebenarnya belum terlalu lama. Perintisan Total Quality Management (TQM) dalam bidang pendidikan diawali di Amerika Serikat pada akhir tahun 1980-an, diikuti oleh Inggris. Peningkatan perhatian baru dimulai pada tahun 1990. Dapat disimpulkan bahwa baru sedikit pemahaman pentingnya mutu terpadu bagi suatu sistem ekonomi dan pendidikan yang sehat. Banyak ahli pendidikan tidak suka membuat analogi antara 'proses pendidikan', dengan 'proses manufaktur', pada industri. ${ }^{9}$

Merancang sistem manajemen mutu dengan adanya sistem manajemen mutu dalam suatu institusi perguruan tinggi, menjamin terlaksananya perbaikan mutu secara berkelanjutan. Dalam penerapan TQM, institusi harus menyusun sistem mutu dalam bentuk pedoman mutu (Quality Manual), tertulis sebagai acuan bagi semua orang yang terlibat dalam pencapaian standar-standar kinerja mutu yang ditetapkan. Implementasi sistem manajemen mutu harus diaudit secara berkala dalam rangka memperoleh masukan untuk manajemen review untuk penyempurnaan sistem itu sendiri. ${ }^{10}$

Perencanaan sistem mutu merupakan serangkaian langkah-langkah penting yaitu:

${ }^{7}$ James A.F. Atoner R. Edwar Feeman, Management Sixty edition (Cet. I; New Jersey: Prentice Hall, 1995) h. 7

${ }^{8}$ Ibid

${ }^{9}$ Lihat Ahmad Fadli HS, Organisasi dan Administrasi (Cet. III; Kediri: Manhalun Nasiin Press, 2002), h. 26.

${ }^{10}$ Robert Kritiner, Management (Cet. IV; Boston: Hougton Mifflin, 1999), h. 9 
1. Menetapkan apa yang akan dikerjakan,

2. Mencari dan menetapkan metoda-metoda dan prosedur yang diperlukan untuk menjamin mutu,

3. Mendokumentasikan apa yang akan dikerjakan (pedoman, metoda, prosedur tertulis (prosedur operasional standar) atau sop,

4. Melaksanakan kegiatan sesuai apa yang disepakati secara tertulis,

5. Menyiapkan bukti-bukti tentang apa yang dikerjakan (memungkinkan informasi ini digunakan pihak lain).

6. Sistem Mutu Dalam Bidang Pendidikan

Suatu sistem (jaminan) mutu dalam bidang pendidikan, pada umumnya memuat unsur-unsur sebagai berikut:

a. Rencana Strategis

Rencana strategis memberi visi, misi dan tujuan suatu perguruan tinggi dalam jangka panjang serta memberikan arahan terhadap pelaksanaan seluruh program operasional yang disusun tahun demi tahun. Rencana strategis mengidentifikasi sasaran pasar, positioning dan budaya yang diinginkan dalam memproduksi produk (lulusan) untuk memenuhi pasar tersebut. Rencana strategis sangat penting untuk pencapaian mutu pelayanan sebab hanya perencanaan yang dapat memberikan perspektif keadaan persaingan di masa mendatang. ${ }^{11}$

b. Kebijakan Mutu

Kebijakan mutu merupakan acuan umum bagi program-program utama yang semestinya disusun untuk mengantisipasi kebutuhan dan persyaratan mutu masyarakat. Kebijakan ini seyogyanya merupakan persyaratan kepada masyarakat tentang komitmen perguruan tinggi untuk memuaskan harapan pelanggan baik internal maupun eksternal. Kebijakan mutu harus terdokumentasi, dikomunikasi-kan kepada seluruh staf (akademik dan non akademik) agar dipahami dan selanjutnya memberikan komitmen pada implementasinya.

c. Tanggung Jawab Manajemen

Unsur ini meletakkan peranan dan tanggung jawab manajemen puncak, manajemen madya dalam sistem mutu. Harus ditetapkan juga anggota tim senior yang memimpin pelaksanaan program perbaikan mutu.

d. Organisasi Mutu

Ruang lingkup tugas, wewenang dan tanggung jawab kelompok pengarah untuk mengimplementasikan sistem mutu perlu ditetapkan kelompok atau tim, ini diperlukan untuk:

1) Mengarahkan langkah awal perbaikan mutu,

2) Mengelola perubahan budaya mutu,

${ }^{11}$ Ibid, h. 10 
3) Mendukung dan mengendalikan kegiatan-kegiatan unit kerja dalam langkah awal tersebut.

4) Memonitor perkembangan program perbaikan mutu.

Fungsi tim dalam melaksanakan program dan pemecahan masalah merupakan titik berat dari langkah awal perbaikan mutu. Dukungan, kepemim-pinan dan sumberdaya serta adanya pelatihan tim diperlukan untuk menyukseskan gerakan awal ini. ${ }^{12}$

\section{e. Pemasaran dan Publikasi}

Suatu institusi pendidikan, misalnya perguruan tinggi perlu memberikan informasi yang jelas mengenai program-program studi yang ditawarkan secara lengkap. Informasi ini harus didokumentasikan dengan baik dan mudah diperoleh. Bahan-bahan pemasaran (sales kits) seperti selebaran, leaflet, brosur, iklan dan sebagainya harus dibuat dengan jelas dan tepat serta secara teratur diperbaharui.

\section{f. Seleksi Masuk}

Seleksi masuk merupakan tahapan sangat penting dalam proses pendidikan. Meskipun tidak ada data pendukung, tetapi pengaruh mutu bahan mentah (calon mahasiswa) terhadap mutu lulusan sangat besar. Prosedur seleksi masuk ke perguruan tinggi harus didokumentasikan dengan baik dan di review secara teratur. Hal-hal yang perlu didokumentasikan mencakup pedoman seleksi, surat lamaran asli (termasuk lampirannya), hasil wawancara, daftar nama. ${ }^{13}$

\section{g. Rancangan Kurikulum}

Rancangan kurikulum mencakup maksud dan tujuan setiap Program Studi Pendidikan Agama Islam dan spesifikasinya secara rinci, harus didokumentasikan. Studi prosedur pembukaan/program penetapan harus ada dan didokumentasikan. Spesifikasi meliputi silabus dan satuan acara perkuliahan/praktikum harus disahkan oleh pejabat tertentu. Adanya masukan dari mahasiswa, alumni dan 'client' bagi rancangan kurikulum merupakan bagian sistem mutu yang perlu didokumentasikan dengan baik. Tinjauan secara periodik dalam rangka meningkatkan relevansi dengan dunia kerja perlu diatur secara berkala.

\section{h. Pelaksanaan Kurikulum}

Pelaksanaan kurikulum juga merupakan tahapan penting dalam proses pendidikan. Metode pengajaran harus dimantapkan dan dijelaskan dalam prosedur-prosedur yang harus diikuti dalam pelaksanaan setiap aspek program studi. Berbagai catatan dalam kaitan ini perlu dipelihara dan didokumentasikan dengan baik, antara lain, jadwal kuliah/praktikum, "course submissions", kerangka kerja, catatan kerja, catatan penilaian, rencana kerja dan catatan-catatan prestasi kerja. Demikian pula catatan-

12 Lihat Muchtar Effendi, Manajemen Suatu Pendekatan berdasarkan Ajaran Islam (Jakarta: Bharata, 1996), h. 75

\section{Ibid}


catatan kegagalan dan kinerja di bawah standar dan tindakan koreksi yang diambil harus didokumentasikan. Sistem yang dikembangkan untuk membantu memecahkan masalahmasalah pembelajaran juga perlu didokumentasikan. Rincian penilaian formatif dan sumatif serta kriteria untuk kelulusan dan "'grading" mahasiswa merupakan unsur yang penting dalam pelaksanaan kurikulum. ${ }^{14}$

i. Manajemen Pembelajaran

Proses yang dilaksanakan dalam rangka pengembangan program dan kurikulum perlu dispesifikasi, termasuk pengaturan untuk kerja tim. Peranan dalam tim, wewenang dan tanggung jawab perlu dijelaskan dengan baik. Paparan audit dari pihak luar merupakan bukti yang baik bila tersedia untuk memberikan gambaran, mutu manajemen pembelajaran.

j. Penyusunan, Pelatihan dan Pengembangan Staf

Dosen harus sesuai dengan tugasnya. Perlu dibuat prosedur seleksi dan rekruitmen staf, pengukuran prestasi kerja, peningkatan inovasi dan kebijakan pengembangan karir. Pengembangan staf memerlukan perencanaan dan proses analisis kebutuhan serta sistem monitoring dan evaluasi efektivitas program pelatihan baik jangka pendek maupun jangka panjang. Perlu dilakukan standarisasi bagi kualifikasi staf untuk melaksanakan setiap program studi.

k. Monitoring dan Evaluasi

Siklus umpan balik sangat vital peranannya untuk menilai dan menjamin mutu pendidikan. Sistem mutu dalam kaitan ini mendokumentasikan mekanisme evaluasi yang digunakan instansi untuk memonitor hasil yang dicapai individu-individu dan keberhasilan program yang dilaksanakannya.

Keikutsertaan mahasiswa dalam penilaian kemajuannya sendiri dan pengalaman mereka mengikuti program merupakan unsur penting dalam proses penilaian. Metode yang digunakan dapat terdiri dari analisis dari catatan pencapaian hasil, review meeting, penyebaran kuesioner dan internal audit.

\section{Pengaturan Administrasi}

Perguruan tinggi perlu mendokumentasikan prosedur-prosedur adminis-trasi yang penting meliputi daftar mahasiswa, catatan-catatan mahasiswa, jadwal, prosedur kesehatan dan keamanan, 'examination entries and result' dan sistem keuangan.

Proses pengendalian dokumen penting, namun perlu melakukan spesifikasi terhadap dokumen-dokumen kunci agar tidak terlalu menitik beratkan kepada catatan. Dokumen kunci meliputi silabus terbaru, dokumen persetujuan dan pengesahan, catatan kemahasiswaan, catatan penilaian dan hasil ujian, catatan notulen rapat penting dan sebagainya. ${ }^{15}$

\footnotetext{
${ }^{14} \mathrm{Ibid}$

${ }^{15}$ Ibid, h. 22
} 
m. Review Manajemen Institusi

Perguruan tinggi harus mempunyai suatu cara untuk mengevaluasi keseluruhan kinerja (total performance). Kegiatan ini dapat dilakukan oleh pemeriksa dari luar. Namun demikian, bisa saja diputuskan bahwa perguruan tinggi melakukan audit sendiri dengan melibatkan pihak luar. Sistem Manajemen Mutu yang disusun harus mencakup:

1) Kebijakan mutu dan sasaran mutu.

2) Manual mutu, yang terdiri dari struktur organisasi lembaga, struktur organisasi mutu, uraian wewenang dan tanggung jawab fungsi mutu, garis besar sistem manajemen mutu yang diterapkan oleh institusi, serta prosedur-prosedur yang disyaratkan.

3) Semua dokumen yang dibutuhkan organisasi untuk memastikan keefektifan pengoperasian dan pengendalian proses. Bisa berbentuk strategi organisasi, prosedur kerja, peraturan/tata tertib.

4) Catatan mutu yang disyaratkan, berisi daftar dokumen yang perlu disimpan, berapa lama penyimpanan serta disimpan oleh siapa menggunakan 8 klausul/prinsip utama, ${ }^{16}$ sebagai berikut:
a) Berfokus pada pelanggan,
b) Kepemimpinan,
c) Peran serta setiap orang di dalam organisasi,
d) Pendekatan proses,
e) Pendekatan sistem,
f) Peningkatan terus menerus,
g) Pengambilan keputusan harus dengan pendekatan fakta,
h) Hubungan baik dengan pemasok. ${ }^{17}$

Rencana Program TQM Untuk Universitas/Fakultas dan Program Studi Rencana program kerja TQM pada suatu Universitas/Fakultas/Program Studi, adalah sebagai berikut:

1. Merancang sistem manajemen mutu, dalam bentuk pedoman mutu (quality manual) secara tertulis sebagai acuan bagi civitas akademika yang terlibat dalam pencapaian standar-standar kinerja mutu yang ditetapkan.

2. Membuat Tim Pengarah dan Tim Pelaksana untuk mendesain, mendiagnosa sistem manajemen mutu sebelum dilembagakan dalam struktur organisasi.

3. Menyusun serta menetapkan kebijakan dan tujuan mutu di tingkat program studi, serta mengusulkannya di tingkat fakultas dan universitas. Kemudian menyusun indikator kinerja mutu dan sasaran kinerja mutu.

${ }^{16}$ Ibid, h. 23

17 Handoko, Manajemen Personalia dan Sumber Daya Manusia, Edisi 2 (Yogyakarta: BPEF, 1992), h. 4. 
4. Mulai melaksanakan proyek-proyek perbaikan mutu di Fakultas/Program Studi, antara lain: Penyusunan Buku Pedoman Akademik untuk Mahasiswa; Buku Kurikulum dengan seluruh derivasinya seperti: Satuan Acara Perkuliahan, Analisis Instruksional, Modul Plan, Course Outline, Bahan Ajar Program Studi, pengembangan manajemen sumberdaya manusia, sumberdaya sarana fisik/fasilitas dan sarana komunikasi dan informasi teknologi, keuangan, evaluasi akademik untuk mahasiswa dan staf pengajar, proses belajar mengajar, proses tugas akhir, proses ujian akhir semester dan ujian sarjana dan sebagainya.

5. Menerapkan dan melaksanakan sistem manajemen mutu di Fakultas/Program Studi, ${ }^{18}$ dan melaksanakan monitoring dan evaluasi terhadap kinerja mutu dengan indikator yang telah ditetapkan.

\section{B. Metodologi Penelitian}

\section{Jenis Penelitian}

Penelitian ini adalah penelitian deskriptif yang merupakan suatu bentuk penelitian ditujukan untuk mendeskripsikan fenomena-fenomena yang ada, baik fenomena alamiah maupun fenomena buatan manusia. Fenomena itu bisa berupa bentuk, aktivitas, karakteristik, perubahan, hubungan, kesamaan, dan perbedaan antara fenomena yang satu dengan fenomena lainnya. ${ }^{19}$

Dalam penelitian kualitatif misalnya, teknik pengumpulan data yang utama yaitu menggunakan daftar wawancara tertulis kepada informan, data yang diperoleh adalah data kualitatif. Selanjutnya untuk memperkuat dan mengecek validitas data hasil wawancara tersebut, maka dapat dilengkapi dengan observasi atau wawancara kepada informan yang telah memberikan jawaban pertanyaan yang diajukan penulis, atau orang lain yang memahami terhadap masalah yang diteliti ${ }^{20}$. Karena adanya data kualitatif melalui wawancara mendalam kepada pihak pengelola universitas yang berwenang memberikan informasi sehingga penulis dapat menyusun suatu proporsi.

Dapat dikatakan bahwa penelitian kualitatif yang dimaksudkan ini adalah suatu upaya untuk mengungkapkan secara mendalam mengenai beberapa hal yang berkaitan dengan prospek pengembangan Program studi PAI pada Fakultas Tarbiyah dan Keguruan UIN Alauddin Makassar.

\section{Pendekatan Penelitian}

a. Pendekatan sosiologis dan filosofis digunakan agar transformasi pendidikan Islam dapat berjalan konsisten ke arah tujuan pendidikan Islam. Dengan aspek sosiologis dan filosofis yang bersifat ideal-fleksibel dan kontekstual akan

18 Bambang Sudibyo, Rencana Strategis Depdiknas Tahun 2005-2009 Menuju Pembangunan Pendidikan Nasional Jangka Panjang 2025 (Cet. I; Jakarta: Depdiknas, 2005), h. 7.

${ }^{19}$ Sukmadinata, Metode Penelitian Pendidikan (Bandung: Rosdakarya, 2006), h. 72.

${ }^{20}$ Sugiyono, Metode Penelitian Pendidikan Pendekatan Kualitatif, Kualitatif, dan R\&D (Bandung: Alfabeta, 2008), h. 38-39. 
mengungkapkan makna inti, hakikat atau hikmah dari uraian-uraian yang menjadi fokus dalam pembahasan.

b. Pendekatan pedagogis diterapkan sebab pengelola pendidikan adalah manusia dalam hal ini makhluk Tuhan yang memerlukan proses bimbingan dan pengarahan ke arah pola hidup yang harmonis antara kepentingan hidup di dunia dan akhirat, sejalan dengan tugas pokoknya sebagai khalifah.

c. Pendekatan Fenomenologis digunakan untuk mengarahkan paradigma peserta didik menjadi intelektual muslim yang berakhlakul karimah yang penuh tanggung jawab dan kreatif dalam mengembang amanah. Sedangkan pendekatan normatif teologis digunakan untuk memberikan jastifikasi dari nash-nash Al-Qur'an dan Hadis secara oprasional.

\section{Sumber Data}

Penelitian ini menggunakan 2 (dua) jenis data, yaitu:

a. Data primer, merupakan data utama yang diambil langsung dari para informan yang dalam hal ini adalah dekan, pembantu dekan, ketua program studi, sekertaris program studi, para dosen, dan peserta didik itu sendiri. Data ini berupa hasi interview (wawancara).

b. Data sekunder, pengambilan data dalam bentuk dokumen-dokumen yang telah ada serta hasil penelitian yang ditemukan peneliti secara tidak langsung. Data ini berupa dokumentasi penting menyangkut profil lembaga, dokumen kurikulum, petunjuk teknis pengembangan silabus di Program studi PAI Fakultas Tarbiyah dan Keguruan UIN Alauddin Makassar

\section{Instrumen Penelitian}

Instrumen penelitian yang digunakan adalah:

a. Pedoman wawancara (interview) sebagai pengingat dan penanda pertanyaan yang harus ditanyakan atau telah ditanyakan kepada informan.

b. Pedoman observasi (ceklis untuk data observasi)

c. Buku catatan (untuk mencatat fenomena yang terjadi di lapangan yang berkaitan dengan permasalahan penelitian)

d. Recorder (alat perekam) utuk mempermudah peneliti dalam menyimpan jawaban lisan dari informan.

\section{Metode Pengumpulan Data}

a. Wawancara, yaitu suatu bentuk komunikasi verbal, semacam percakapan yang bertujuan memperoleh data yang mendalam dalam komunikasi tersebut yang dilakukan secara berhadapan ${ }^{21}$. Dalam penelitian ini, wawancara dilakukan untuk menunjang data yang dikumpulkan lewat naskah-naskah.

\footnotetext{
${ }^{21}$ S. Nasution, Metode Research (Jakarta: Bumi Aksara, 2000), h. 113.
} 
b. Dokumentasi, yaitu dalam konsep umum terbatas hanya pada bahan-bahan tertulis saja dalam berbagai kegiatan. $^{22}$ Dokumentasi adalah proses pengumpulan, pemilihan, dan pengelolaan naskah-naskah asli atau informasiinformasi tertulis yang dipergunakan sebagai alat pembuktian atau bahan untuk mendukung suatu keterangan atau argumen ${ }^{23}$. Naskah-naskah atau informasi tertulis (dokumen) yang diteliti pada penelitian ini adalah naskah-naskah yang berkaitan dengan variabel penelitian.

\section{Metode Pengolahan dan Analisis Data}

Data yang terkumpul kemudian diolah dengan menggunakan teknik deskriptif. Teknik analisis deskriptif yang dimaksud dalam penelitian ini adalah analitik non statistik dengan pendekatan induktif yaitu suatu analisis data yang bertolak dari problem atau pernyataan maupun tema spesifik yang dijadikan fokus penelitian. ${ }^{24}$ Jika dikaitkan dengan penelitian ini, maka Prospek pengembangan Program studi PAI Fakultas Tarbiyah dan Keguruan UIN Alauddin Makassar, akan diamati lalu hasil pengematan tersebut akan digambarkan sebagaimana adanya, baik berupa problem strategi pembelajaran yang menjadi sumber data dan tema penelitian itu sendiri dalam hubungannya dengan hasil pembelajara yang dianggap sebagai akumulasi prestasi lembaga pada program studi PAI tersebut.

Penulis menempuh tiga cara dalam mengolah data penelitian ini:

a. Reduksi data adalah proses memilih, menyederhanakan, memfokuskan, mengabstraksi dan mengubah data kasar yang muncul dari catata-catatan lapangan. ${ }^{25}$ Reduksi data dimaksudkan untuk menentukan data ulang sesuai dengan permasalahan penelitian.

b. Sajian data atau display data adalah suatu cara merangkai data dalam suatu organisasi yang memudahkan untuk membuat kesimpulan atau tindakan yang diusulkan. ${ }^{26}$ Sajian data pada peneltian ini adalah memilih data yang disesuaikan dengan kebutuhan penelitian.

c. Verifikasi atau penyimpulan data yaitu penjelasan tentang makna data dalam suatu konfigurasi yang secara jelas menunjukkan alur kausalnya, sehingga dapat diajukan proposisi yang terkait dengannya. ${ }^{27}$ Verivikasi dalam penelitian ini digunakan untuk penentuan hasil akhir dari keseluruhan proses tahapan analisis, sehingga keseluruhan permasalahan dapat dijawab sesuai dengan

\footnotetext{
${ }^{22}$ Ibid., h. 115.

${ }^{23}$ Komaruddin, Kamus Istilah Skripsi dan Tesis (Bandung: Angkasa, 1985), h. 33.

${ }^{24}$ Sugiyono, op. cit., h. 11.

${ }^{25}$ Muhammad Ali, Strategi Penelitian Pendidikan (Bandung: Angkasa, 1993), h. 167.

${ }^{26}$ Ibid, h. 168.

${ }^{27}$ Ibid.
} 
kategori data dan masalahnya. Pada bagian ini akan muncul kesimpulankesimpulan yang mendalam secara komprehensif dari data hasil penelitian.

\section{Uji Keabsahan Data}

Menguji kredibilitas data dengan teknik trianggulasi yaitu mengecek data kepada sumber yang sama dengan teknik yang berbeda. Misalnya mengungkap data tentang pengembangan pengelolaan pembelajaran, aktifitas pembelajaran mahasiswa dengan teknik wawancara, lalu dicek dengan observasi ke ruagan kemudian dengan dokumentasi. Bila ternyata diperoleh situasi yang berbeda maka peneliti perlu melakukan diskusi lebih lanjut dengan sumber data atau yang lain untuk memastikan data yang dianggap benar. ${ }^{28}$

\section{Mencermati Pengembangan Program Studi PAI Fakultas Tarbiyah dan Keguruan UIN Alauddin Makassar}

\section{Profil Program Studi Pendidikan Agama Islam Fakultas Tarbiyah dan Keguruan UIN Alauddin Makassar}

Program Studi Pendidikan Agama Islam merupakan jurusan yang telah ada bersamaan dengan lahirnya Fakultas Tarbiyah pada tahun 1964 berdasarkan Surat Keputusan Menteri Agama Nomor: 91 tahun 1964. Berdasarkan keputusan Direktur Jenderal Pembinaan Kelembagaan Agama Islam Nomor: E/50/1999 tentang Penyelenggaraan Jurusan dan Program Studi pada Institut Agama Islam Negeri Alauddin Makassar di tetepkan di Jakarta tertanggal 25 Maret 1999. ${ }^{29}$ Seiring pertambahan usia tersebut, peningkatan kualitas pendidikan merupakan hal yang tidak dapat dielakkan. Apalagi dengan adanya perubahan struktur kelembagaan dari IAIN ke UIN Alauddin Makassar pada tahun 2005, berdasarkan Praturan Presiden Republik Indonesia Nomor 57 Tahun 2005 ditetapkan di Jakarta tertanggal 10 Oktober 2005. ${ }^{30}$

Visi Program Studi Pendidikan Agama Islam Fakultas Tarbiyah dan Keguruan UIN Alauddin Makassar adalah sebagai wadah pengembangan dan pembinaan tenaga pendidikan agama Islam yang profesional. Demi mewujudkan visi tersebut, diupayakan Misi sebagai berikut:

a. Membentuk tenaga pendidik yang menguasai ilmu pengetahuan agama Islam

b. Membina tenaga pendidik agama Islam yang mencintai tugasnya

c. Meningkatkan kualitas tenaga pendidikan agama Islam baik aqidah, akhlak maupun sikap ilmiah

d. Mempersiapkan tenaga ahli di bidang pengajaran dan pendidikan agama islam

\footnotetext{
${ }^{28}$ Ibid.

${ }^{29}$ Kumpulan peraturan Akademik UIN Alauddin Makassar Tahun, 2010, h.196

30 Arsip Lampiran Akreditasi I Program Studi Pendidikan Agama Islam Fakultas Tarbiyah dan Keguruan UIN Alauddin Makassar, Tahun, 2006.
} 
e. Mempersiapkan tenaga profesional dibidang pengajaran Islam untuk mengajar di lembaga-lembaga pendidikan Madrasah Aliyah dan yang sederajat. ${ }^{31}$

Sehubungan dengan itu, Program Studi Pendidikan Agama Islam Fakultas Tarbiyah dan Keguruan UIN Alauddin Makassar perlu mempersiapkan diri dengan merekrut dosen tetap PAI sesuai dengan bidang dan keahliannya. Berikut ini daftar dosen tetap program studi PAI tahun 2010/2011.

\section{Tabel: I}

Keadaan Dosen Tetap Program Studi PAI Fakultas Tarbiyah dan Keguruan UIN Alauddin Makassar Tahun Akademik 2010/2011

\begin{tabular}{|c|l|c|}
\hline No. & \multicolumn{1}{|c|}{ Jabatan Akademik } & Jumlah \\
\hline 1 & Guru Besar & 16 \\
\hline 2 & Lektor Kepala & 3 \\
\hline 3 & Lektor & 22 \\
\hline & Total Jumlah & . \\
\hline
\end{tabular}

Sumber data: Data dosen tetap program studi PAI tahun akademik 2010/2011

Program studi PAI berkembang cukup menggembirakan baik secara kualitas maupun kuantitasnya. Saat ini data mahasiswa program studi Pendidikan Agama Islam berjumlah 448 peserta mahasiswa PAI. Berikut ini tabel jumlah mahasiswa Pendidikan Agama Islam (PAI).

\section{Tabel: II}

Data Mahasiswa Program Studi PAI Fakultas Tarbiyah dan Keguruan UIN Alauddin Makassar Tahun Akademik 2010/2011

\begin{tabular}{|c|c|c|c|}
\hline No & Tahun Akademik & Semester & Jumlah \\
\hline 1 & $2010 / 2011$ & I (satu) & 77 \\
\hline 2 & $2009 / 2010$ & III (tiga) & 58 \\
\hline 3 & $2008 / 2009$ & V (lima) & 86 \\
\hline 4 & $2007 / 2008$ & VII,IX,XI & 277 \\
\hline \multicolumn{2}{|r}{} & Total Jumlah & 448 \\
\hline
\end{tabular}

Sumber data: Data mahasiswa program studi PAI tahun akademik 2010/2011.

Semakin meningkatnya animo dan perhatian masyarakat Prodi PAI banyak diminati oleh masyarakat dengan adanya berbagai program PAI yg dilaksanakan dan mendapat perhatian oleh pemerintah dan instansi terkait yang ikut memikirkan pengembangan Prodi PAI ke depan hanya kementerian Agama Sulawesi Selatan Bid. Mapenda memberikan kinerja secara formal. Pendapat senada dinyatakan oleh mantan Dekan Fakultas Tarbiyah dan Keguruan UIN Alauddin Makassar, H. Moh. Natsir Mahmud, bahwa Prodi PAI banyak diminati oleh masyarakat dan para dosen PAI sangat

\section{${ }^{31}$ Ibid.}


relevan sesuai dengan keahliannya( profesor di bidangnya) dan hasil BAN- PT Prodi PAI memperoleh nilai Akreditasi A. Terakreditasinya Prodi PAI Fakultas Tarbiyah dan Keguruan berhak atas proyek sertifikasi guru dan mempunyai peluang untuk membuka beberapa program pendidikan dalam kememterian Agama Pusat ${ }^{32}$

\section{Upaya Pengembangan Program Studi PAI pada Fakultas Tarbiyah dan Keguruan UIN Alauddin Makassar}

Berbagai upaya dalam pengembangan Program Studi PAI Fakultas Tarbiyah dan Keguruan UIN Alauddin Makassar adalah sebagai berikut:

\section{a. Efisiensi dan Efektivitas Kepemimpinan}

Kepemimpinan dan pengembangan lembaga yang ada sekarang cukup memadai dilihat dari latar belakang pendidikan dan pengalamannya. Dalam menyebarluaskan kebijakan, unsur pimpinan berusaha menempuh sistem dan strategi tertentu antara lain: menyiapkan dan melaksanakan pengendalian administrasi dalam kegiatan organisasi agar terarah sesuai tujuan, menciptakan sistem administrasi yang terpadu dalam menjamin terciptanya pengambilan keputusan yang efektif dan efisien, serta menetapkan sistem administrasi sesuai dengan perkembangan agar dapat memberikan informasi secara cepat, tepat dan benar.

\section{b. Evaluasi Program dan Pelacakan Lulusan}

Hasil dari pelacakan alumni tersebut telah dimanfaatkan oleh pimpinan universitas untuk peningkatan perbaikan program dan perencanaan program yang lebih baik di masa mendatang. Perbaikan program yang telah dilakukan adalah penyempurnaan kurikulum, perbaikan sarana dan prasarana gedung dan ruang kuliah, perbaikan sarana perkuliahan, dan peningkatan pelayanan administratif yang kondusif, cepat, tepat dan ramah.

\section{c. Perencanaan dan Pengembangan Program}

Berpijak pada hasil evaluasi program, baik secara internal maupun eksternal, Program Studi PAI Fakultas Tarbiyah UIN Alauddin Makassar melakukan perencanaan dan pengembangan program yang lebih terarah, menyangkut proses implementasi tridarma. Dengan tetap mepertimbangkan keterbatasan sumberdaya, baik biaya, waktu, maupun kendala-kendala lainnya, Program Studi PAI Fakultas Tarbiyah dan Keguruan UIN Alauddin Makassar melakukan perencanaan dan pengembangan program difokuskan pada visi, misi, tujuan, dan kebutuhan masyarakat pengguna.

Adapun peningkatan mutu dilakukan sebagai upaya untuk meningkatkan kualitas Program Studi PAI Fakultas Tarbiyah dan Keguruan UIN Alauddin Makassar sebagai institusi pendidikan yang mampu menjawab berbagai tantangan dan kebutuhan

${ }^{32}$ H. Moh. Natsir Mahmud, Direktur Pascasarjana UIN Alauddin Makassar, wawancara, pada tanggal 5 Mei 2011. 
masyarakat atas ilmu pengetahuan dan teknologi, serta mampu bersaing (kompetitif) dalam menarik perhatian mahasiswa dan menghasilkan produk sarjana dan profesional unggulan. ${ }^{33}$

\section{d. Kerja sama dan Kemitraan}

Berpedoman pada Keputusam Menteri Pendidikan Nasional No 223/U/1998 tentang Kerjasama antar Perguruan Tinggi Program Studi PAI Fakultas Tarbiyah dan Keguruan UIN Alauddin Makassar memandang kerja sama dan kemitraan sebagai strategi yang perlu dikembangkan untuk pembinaan dan pengembangan Program Studi PAI Fakultas Tarbiyah dan Keguruan UIN Alauddin Makassar. Program Studi telah meningkatkan kerja sama dan kemitraan dengan Perguruan Tinggi/lembaga lain, baik instansi pemerintah maupun swasta. Kerja sama yang telah dilakukan adalah dalam implementasi tridarma. Dalam pendidikan dan pengajaran, kerjasama dilakukan dengan , GPAI (SI) SD/MI, GPAI (SI) Dual Mode System (DMS), GPAI (SI) kualifikasi ke jenjang (SI), Madrasah Education Devlopment Project (MEDP), tentang proses pembelajaran ke jenjang sarjana (SI), dengan Madrasah Pendidikan Agama (Mapenda) Kemenag RI tentang peningkatan mutu tenaga pendidik dan kependidikan, di lingkungan Program Studi PAI Fakultas Tarbiyah dan Keguruan UIN Alauddin Makassar. ${ }^{34}$

Kerja sama dan kemitraan tersebut, baik kuantitas maupun kualitasnya, masih terus ditingkatkan hingga sekarang, dengan lembaga yang telah bekerja sama maupun lembaga lainnya.

\section{e. Evaluasi Program terhadap Pengalaman dan Mutu Pembelajaran Mahasiswa}

Hasil evaluasi program ini, baik secara internal maupun eksternal, terutama aspek kelemahan (weakness) berkaitan belum optimalnya implementasi program dijadikan tolok ukur oleh Program Studi PAI Fakultas Tarbiyah dan Keguruan UIN Alauddin Makassar untuk peningkatan mutu pembelajaran kepada mahasiswa, sehingga mengalami peningkatan dari tahun ke tahun. Hal ini dapat dibuktikan antara lain dengan adanya peningkatan intensitas dan metode pembelajaran, sarana dan prasarana pembelajaran, dan mutu lulusan.

Program Studi Pendidikan Agama Islam (PAI) pada Fakultas Tarbiyah dan Keguruan UIN Alauddin Makassar senantiasa mengembangkan nilai-nilai pembelajaran yang berbasis IPTEK dan tidak mengabaikan nilai-nilai moralitas (IMTAQ) hal ini sejalan dengan visinya yakni " Program Studi Pendidikan Agama Islam (PAI) pada Fakultas Tarbiyah dan Keguruan UIN Alauddin Makassar Membentuk tenaga pendidik

33 Abd.Rahman Getteng, Dosen tetap Prodi PAI Fakultas Tarbiyah dan Keguruan UIN Alauddin Makassar, Wawancara, pada tanggal 1 Mei 2011.

${ }^{34}$ Suddin Bani, Sekretaris Prodi PGMI Fakultas Tarbiyah dan Keguruan UIN Alauddin Makassar, Wawancara, pada tanggal 23 Mei 2011. 
yang menguasai ilmu pengetahuan agama Islam dan meningkatkan kualitas tenaga pendidik agama Islam baik aqidah, akhlak maupun sikap ilmiah." 35

Untuk mewujudkan visi di Program Studi Pendidikan Agama Islam (PAI) pada Fakultas Tarbiyah dan Keguruan UIN Alauddin Makassar maka semua dosen mempunyai peran penting dalam peningkatan SDM, sesuai dengan cirinya sebagai pendidikan agama islam, secara ideal program studi pendidikan agama Islam berfungsi dalam penyiapan calon guru yang memiliki SDM yang berkualitas tinggi, baik dalam penguasaan terhadap ilmu pengetahuan dan teknologi (IPTEK) maupun dalam hal karakter, sikap moral, dan Iman dan Taqwa (IMTAQ), serta penghayatan dan pengamalan ajaran agama. Secara ideal menurut penulis program studi PAI pendidikan berfungsi membina dan menyiapkan calon pendidik yang berilmu, berteknologi, berketerampilan tinggi dan sekaligus beriman dan beramal shaleh.

Dalam kerangka perwujudan fungsi ideal pendidikan untuk meningkatkan kualitas SDM tersebut, sistem pendidikan Islam haruslah senantiasa mengorientasikan diri untuk menjawab kebutuhan dan tantangan yang muncul dalam masyarakat khususnya dilingkungan UIN Alauddin Makassar sebagai konsekwensi logis dari perubahan. Meskipun Indonesia telah mencapai kemajuan seperti itu, pembangunan tentu saja belum berakhir, Bahkan sebaliknya, Indonesia harus semakin meningkatkan momentum pembangunannya. Untuk itu, tidak ada alternative lain, kecuali penyiapan calon pendidik yang memiliki SDM yang berkualitas tinggi dan dibarengi dengan nilainilai moralitas, menguasai ilmu pengetahuan dan teknologi, serta keahlian dan keterampilan. Hanya dengan tersedianya SDM yang berkualitas tinggi itu, Indonesia bisa survive di tengah pertarungan ekonomi politik Internasional.

Karena itu menurut peneliti, sudah saatnya bagi dosen khususnya di program studi PAI ini untuk lebih serius menagani pembaruan dan pengembangan sistem pendidikan yang berbasis IPTEK. Selama ini usaha ke arah peningkatan SDM sering bersifat sepotong-sepotong atau tidak komperhensif dan menyeluruh. Sebab usaha pembaruan dan peningkatan SDM dilakukan seadanya, maka tidak terjadi perubahan esensial dalam sistem pendidikan, sistem pendidikan di Indonesia lebih cenderung berorientasi ke masa silam ketimbang berorientasi ke masa depan.

\section{Faktor Pendukung dan Penghambat Pengembangan Program Studi PAI Fakultas Tarbiyah dan Keguruan UIN Alauddin Makassar}

\section{a. Faktor Pendukung}

Penguatan kelembagaan yang dimiliki Program Studi Pendidikan Agama Islam (PAI) pada Fakultas Tarbiyah dan Keguruan UIN Alauddin Makassar menjadi faktor pendukung dalam pengembangan, yaitu; ${ }^{36}$

${ }^{35}$ Muzakkir, Sekretaris Prodi PAI Fakultas Tarbiyah dan Keguruan UIN Alauddin Makassar, Wawancara, pada tanggal 23 Mei 2011.

${ }^{36}$ Susdiyanto, Ketua Prodi PAI Fak. Tarbiyah dan Keguruan UIN Alauddin Makassar, Wawancara pada tanggal, 27 Mei 2011. 
1) Pengalaman dalam pengembangan pendidikan sudah cukup lama

Program studi PAI beroprasi sejak tahun 1964. Pengelolaan yang berlangsung 53 tahun tersebut tergolong lama dengan berbagai tenaga berpengalaman tentunya sangat mendukung dalam pengembangan program studi ke depan. Berbagai permasalahan yang telah lalu dapat dijadikan pembelajaran atau bahan evaluasi yang lebih baiknya ke depan.

2) Kepangkatan dan pendidikan para dosen yang mencukupi

Kualitas dosen yang mengajarkan mata kuliah sesuai dengan profesionalis-me yang dimiliki, menjadi pendukung dalam pengembangan program studi PAI. Jumlah dosennya pun memenuhi rasio mahasiswa, tentuya menjadi nilai plus dan persyaratan idealnya suatu program studi.

3) Dukungan pemerintah

Dukungan pemerintah yang memberikan ruang gerak bagi Program studi PAI Fakultas Tarbiyah dan Keguruan UIN Alauddin Makassar untuk menjabarkan keputusan-keputusan pemerintah menjadi keputusan-keputusan yang lebih oprasional dalam fasilitas non fisik peningkatan SDM bagi mahasiswa yang memiliki prestasi dalam studinya, yaitu bantuan berupa beasiswa Yayasan Supersemar, beasiswa PT. Gudang Garam, Beasiswa Bank Indonesia, beasiswa Departement Agama sebagai upaya untuk merealisasikan program Program studi PAI Fakultas Tarbiyah dan Keguruan UIN Alauddin Makassar. Bantuan beasiswa tidak hanya untuk mahasiswa, namun juga untuk tenaga dosen. Selain itu, pemerintah setempat juga memberikan bantuan pengembangan sarana dan prasarana dalam membangun SDM. ${ }^{37}$

Antusiasme pemerintah dalam memberikan dukungan baik moril maupun materil dapat diwujudkan, namun bantuan tersebut sangat terbatas dalam pengembangan Program studi PAI Fakultas Tarbiyah dan Keguruan UIN Alauddin Makassar.

4) Masih banyak peminat Program Studi Pendidikan Agama Islam (PAI) pada Fakultas Tarbiyah dan Keguruan

Jumlah mahasiswa pada Program Studi Pendidikan Agama Islam (PAI) pada Fakultas Tarbiyah dan Keguruan cukup banyak. Bahkan semakin bertambah disetiap tahunnya. Hal ini tentu membanggakan dan menjadi pendukung dalam pengembangan institusi. Sebab kuantitas mahasiswa menjadi salah satu unsur penilaian dalam standar nasional pendidikan, dalam hal ini akreditasi program studi.

\section{b. Faktor Penghambat}

Kelemahan Program Studi Pendidikan Agama Islam (PAI) pada Fakultas Tarbiyah dan Keguruan sebagai faktor penghambat pengembangan, yaitu;

1) Infrastruktur masih belum memadai

${ }^{37}$ H. Marjuni, Dosen tetap Prodi Pendidikan Guru Madrasah Ibtidaiyah (PGMI) Fak. Tarbiyah UIN Alauddin Makassar, Wawancara, pada tanggal 27 Mei 2011. 
Kurangnya infrastruktur seperti media pembelajaran $L C D$ dan laptop menjadi penghambat dalam pengembangan lembaga. Solusinya adalah upaya pengadaan infrastruktur demi lebih baiknya dalam pembelajaran.

2) Disiplin dosen yang kurang memuaskan

Disiplin tinggi yang dimaksud adalah sikap mental yang ditandai oleh adanya konsistensi yang tinggi, dan adanya rasa pengabdian yang tinggi terhadap pekerjaan dan tugas-tugasnya. Solusi yang dilakukan adalah mengupayakan pelatihan dosen, karena mereka dituntut harus lebih kreatif yang mampu melakukan inovasi dan pembaruan. Mengikuti trend zaman dengan persaingan semakin ketat misalnya penguasaan Bahasa Inggris/Arab dan operasi komputer atau penguasaan teknologi merupakan syarat penting untuk berdaya saing tinggi. ${ }^{38}$

3) Sumber dana terkait dengan pengembangan kegiatan progam studi belum tersosialisasikan (Fakultas). ${ }^{39}$

Sistem alokasi dana masih sentralistik, karenanya pengalokasian terkadang tidak sesuai dtenaga pendidikengan kebutuhan program studi. Hal ini menjadi salah satu penghambat dalam pengembangan program studi PAI mengingat ada sektor-sektor yang membutuhkan kucuran dana namun belum teraloksi secara aturan nasional. Sehingga kemandirian ekonomi sangat diperlukan dalam pengembangan suatu program studi, khususnya program studi PAI yang menjadi objek kajian.

\section{PENUTUP}

Pengelolaan Program Studi PAI pada Fakultas Tarbiyah dan Keguruan UIN Alauddin Makassar menghasilkan Akreditasi A (Tahun 2007) tidak hanya perlu dilihat sebagai pusat ilmu pengetahuan, pusat penelitian, dan pusat pengabdian kepada masyarakat, tetapi juga suatu identitas penghasil ilmu pengetahuan yang perlu bersaing untuk menjamin pengembangan Prodi PAI kedepan. Persaingan, sebagaimana dialami oleh perusahaan profit, meliputi persaingan di bidang mutu, harga, dan layanan.

Pengembangan program semuanya memerlukan pengetahuan ketrampilan manajemen, yaitu manajemen perguruan tinggi, yang menyiapkan peserta didik menjadi tenaga pendidik yg professional bagi masyarakat yang memiliki kemampuan akademik (profesional )yang dapat menerapkan, mengembangkan atau memperkaya khasanah ilmu pengetahuan, teknologi yang dibarengi dengan Iman dan Taqwa, mengembangkan dan menyebarluaskan ilmu pengetahuan, teknologi, serta mengupayakan penggunaannya, para alumni Prodi PAI siap kerja.

${ }^{38}$ H. Abd. Rahman Getteng, Dosen Fakultas Tarbiyah dan Keguruan UIN Alauddin makassar, Wawancara pada tanggal 10 Mei 2011

${ }^{39}$ Muzakkir, Sekretaris Prodi PAI Fakultas Tarbiyah dan Keguruan UIN Alauddin Makassar sejak tahun 2008 sampai sekarang, wawancara pada tanggal 10 Mei 2011 


\section{DAFTAR PUSTAKA}

Ali, Muhammad. Strategi Penelitian Pendidikan. Bandung: Angkasa, 1993.

Azra, Azyumardi. Pendidikan Islam, Tradisi dan modernisasi menuju Milenium Baru. Cet. I; Jakarta: Logos, 1999.

Effendi, Muchtar. Manajemen Suatu Pendekatan berdasarkan Ajaran Islam. Jakarta: Bharata, 1996.

Fadli, Ahmad. Organisasi dan Administrasi. Cet. III; Kediri: Manhalun Nasiin Press, 2002.

Handoko. Manajemen Personalia dan Sumber Daya Manusia, Edisi 2. Yogyakarta: BPEF, 1992.

James A.F. Atoner R. Edwar Feeman. Management Sixty Edition. Cet. I; New Jersey: Prentice Hall, 1995.

Komaruddin. Kamus Istilah Skripsi dan Tesis. Bandung: Angkasa, 1985.

Kritiner, Robert. Management. Cet. IV; Boston: Hougton Mifflin, 1999.

Kumpulan peraturan Akademik UIN Alauddin Makassar Tahun, 2010.

Lampiran Akreditasi I Program Studi Pendidikan Agama Islam Fakultas Tarbiyah dan Keguruan UIN Alauddin Makassar, Tahun, 2006.

Muhaimin. Paradigma Pendidikan Islam Upaya Mengefektifkan Pendidikan Agama Islam di Sekolah. Cet. II; Bandung: PT. Remaja Rosdakarya, 2002.

Nasution, S. Metode Research. Jakarta: Bumi Aksara, 2000.

Profil Fakultas Tarbiyah dan Keguruan UIN Alauddin Makassar tahun 2006.

Saridjo, Marwan. Bunga Rampai Pendidikan Agama Islam. Cet. I; Jakarta: Amisco, 1999.

Rumi, Ahmad. Ensiklopedi Manajemen. Jakarta: Bumi Aksara, 1994.

Sudibyo, Bambang. Rencana Strategis Depdiknas Tahun 2005-2009 Menuju Pembangunan Pendidikan Nasional Jangka Panjang 2025. Cet. I; Jakarta: Depdiknas, 2005.

Sugiyono. Metode Penelitian Pendidikan Pendekatan Kualitatif, Kualitatif, dan R\&D. Bandung: Alfabeta, 2008.

Sukmadinata. Metode Penelitian Pendidikan. Bandung: Rosdakarya, 2006.

Bani, Suddin. Sekretaris Prodi PGMI Fakultas Tarbiyah dan Keguruan UIN Alauddin Makassar, Wawancara, pada tanggal 23 Mei 2011. 
Chaeruddin. Dosen tetap Prodi PAI Fakultas Tarbiyah dan Keguruan UIN Alauddin Makassar, Wawancara, pada tanggal 29 Mei 2011.

Getteng, Abd. Rahman. Dosen Fakultas Tarbiyah dan Keguruan UIN Alauddin makassar, Wawancara, pada tanggal 1 Mei 2011.

Munirah. Dosen tetap Prodi Pendidikan Guru Madrasah Ibtidaiyah (PGMI) Fakultas Tarbiyah UIN Alauddin Makassar, Wawancara, pada tanggal 27 Mei 2011.

Mappanganro. Dosen tetap Prodi PAI Fakultas Tarbiyah dan Keguruan UIN Alauddin Makassar, Wawancara, pada Tanggal 4 Mei 2011.

Muzakkir. Sekretaris Prodi PAI Fakultas Tarbiyah dan Keguruan UIN Alauddin Makassar sejak tahun 2008 sampai sekarang, Wawancara, pada tanggal 23 Mei 2011.

Susdiyanto. Ketua Prodi PAI Fakultas Tarbiyah dan Keguruan UIN Alauddin Makassar, Wawancara, pada tanggal,27 Mei 2011. 